\title{
Environmental Determinants to Household Food Security in Kyangwithya West Location of Kitui County
}

\author{
Kezia Waruguru Mbuthia, Felix N. Kioli, Kennedy B. Wanjala* \\ Department of Sociology and Anthropology, South Eastern Kenya University, Kitui, Kenya \\ *Corresponding author: keziah.waruguru@yahoo.com
}

\begin{abstract}
This study analyzed the environmental determinants to household food security in Kyangwithya West location of Kitui County. Quantitative data were collected using systematic sampling method to select 344 households with the aid of a structured questionnaire. Qualitative data was obtained from key informants and focus group discussants that were purposively sampled. The data were subjected to descriptive statistics and presented using tables and verbatim narratives. The findings revealed that majority (89\%) of the participants had experienced weather changes in the study area and a significant number (27\%) were food secure. Few households (11\%) had not observed any weather change and (28\%) of them were food secure. The weather changes observed were assessed and inadequate rainfall was observed by majority (82\%) of the respondents (26\%) of whom were food secure. High temperatures were reported by (12\%) of the respondents (28\%) of whom were food secure. Recurrent drought was reported by the least number of respondents (6\%) that were the most food secure (30\%). Influence of cutting trees on household food security revealed that majority (82\%) of the respondents do not cut tree and are more food secure (29) compared to the few (18\%) who cut trees. The results reveal that majority of the households observed changes in weather patterns although the percentage of the food secure was low. Inadequate rainfall was the most observed weather change with the most influence on household food security followed by high temperatures and recurrent droughts. Majority of the households did not cut trees and are more food secure than those that cut trees. Environmental factors are thus significant determinants to household food security. The study recommended that regular updates on weather forecast be made available to households to enable them make informed plans during planting seasons.
\end{abstract}

Keywords: household food security, households, Kyangwithya West location, environmental determinants

Cite This Article: Kezia Waruguru Mbuthia, Felix N. Kioli, and Kennedy B. Wanjala, "Environmental Determinants to Household Food Security in Kyangwithya West Location of Kitui County." Journal of Food Security, vol. 5, no. 4 (2017): 129-133. doi: 10.12691/jfs-5-4-3.

\section{Introduction}

Weather changes resulting to increases in average temperatures have been observed around the globe and there is new and stronger evidence that most of the warming observed in the last 50 years is due to human activities [12]. These changes are as a result of climate change which is a long-term shift in weather conditions identified by changes in temperature, precipitation, winds, and other indicators [2]. These changes have the potential to adversely affect the environment, communities and the economy unless action is taken now [12]. For example, a few days of temperatures above or below a certain threshold can damage cereals and fruit tree yields [33]. Globally, weather variability has been experienced with the projected change in average temperature likely to be from $0.3^{\circ} \mathrm{C}$ to $0.7^{\circ} \mathrm{C}$ for the period 2016-2035 relative to the reference period 1986-2005 [22]. In the European heat wave of 2003, when temperatures were $6{ }^{\circ} \mathrm{C}$ above longterm means and contributed to a significant drop in crop yields. This reduction was by 36 percent for maize in Italy, and by 25 percent for fruit and 30 percent for forage in France [18].

Africa and Southern Asia are thought to be among the regions that will be most affected by climate variability because of high dependence on agriculture for livelihoods [10]. In addition, the overall net effect on agricultural production as a result of the changing climate is expected to be negative particularly over the long term since these areas are highly sensitive to changes in rainfall patterns $[17,24]$. Climate change also affect food security between regions in Southern Africa. It is among the most frequently cited drivers of food insecurity because it acts both as an underlying, ongoing issue and as a short-lived shock [16]. In the Indo-Gangetic Plain of India, weather variability has also been reported to have an influence on food security [5].

In Kenya, climate change has contributed to food and financial crises resulting from the frequency of droughts and flash floods which is expected to increase both in intensity and spread [14]. Previously in 1991 in Northern Kenya, 28 percent of cattle; 18 percent of sheep and goats died due to the impact of drought on livestock [30]. This greatly affected the economy of the local community. 
The projected increase in temperatures and rainfall variability will negatively impact crop and livestock enterprises in most areas and food security will be greatly affected. The effects of climate change may range from direct effects on crop production, changes in markets, food prices and supply chain infrastructure. These changes will also have effect on consumption patterns because of increasing costs driven by climate change, households may have to consume unsafe foods which will find their way in the market.[1].

In the ASALs, [6] indicate that climate change and weather variability has resulted to increased drought episodes, food insecurity, and irreversible decline in herd sizes, and deepening poverty in these areas. In addition, it has adversely affecting the lives and livelihoods of smallholder farmers in ASALs [27]. In Kitui County, [29] indicate that climate and weather variability and change in ASALs particularly of lower eastern Kenya has greatly affected yields obtained which is to say that food security has been compromised in Kitui and other counties in Eastern Kenya. Kyangwithya West location situated in the Western parts of Kitui County has also experienced variability to the normally experienced high temperatures which range around $16^{\circ} \mathrm{C}$ to $34^{\circ} \mathrm{C}$, however, the influence of the weather change to household food security is not documented for the study area [7]. Reviewed literature indicates that weather variability has been experienced in many regions of the world [22]. In the study area, the same has been witnessed and an understanding therefore of the influence of the weather changes to HHFS is important. This study therefore sought to establish the influence of weather changes on HHFS.

Deforestation is an important environmental factor because of its impact on land that produces food for households. According to [32], about 15 percent of the world's soils (1,965 million ha) are considered to be moderately to extremely degraded. Reference [32] also indicated that factors responsible for the degradation include water and wind erosion, salinisation, nutrient decline and physical compaction. Deforestation degrades the environment and makes all forms of erosion possible. Changes in forest or tree cover influences regional and global hydrological cycling due to their key role in the water cycle [3]. It is thus expected that deforestation would influence rainfall distribution as it interferes with the water cycle process. An analysis of changes in rainfall over Borneo forest in Indonesia reveals that there has been a constant decline in total annual rainfall between 1951 and 2007. The most abrupt decreases occurred in the 1980s, when intensive deforestation activities (primarily logging) occurred in search of timber for garden furniture, paper pulp and chopsticks [23]. In Asia, an estimated 453 million ha are considered to be moderately to extremely degraded; 315 million due to water erosion, 90 million ha due to wind erosion, 41 million ha due to chemical degradation and 6 million ha due to physical degradation. The yields reduced in food crops due to these various forms of soil erosion can be significant. In Africa, yield reduction caused by past erosion is estimated at 9 percent of total production [11].

In Ethiopia, [26] indicated that deforestation is very high and this provides a well known example of a severely degraded environment together with a decreasing agricultural productivity. The economy of Ethiopia solely depends on agricultural activities and therefore land degradation arising from deforestation is highly affecting the production and productivity of the sector. In Kenya deforestation which involves exploitation of existing forests for charcoal burning, fuel wood, construction materials and fodder leads to food crises [15]. For instance, $64.4 \%$ and 17.0\% of Kenyans use firewood and charcoal respectively while in Kitui County 88.6\% individuals use firewood for fuel which does not stand well with environmental protection [20]. In Kitui, deforestation degrades the environment making it unfit for food production. In Kyangwithya West location, $93.4 \%$ of households use and sell firewood while $4.4 \%$ cut wood for charcoal burning to supplement farming income [20]. Therefore, since land degradation arising from deforestation can easily hamper food security [13], it thus require attention. Therefore, in Kyangwithya West location, the influence of deforestation on HHFS requires further examination. This study therefore aimed at establishing the influence of deforestation on HHFS.

\section{Materials and Methods}

\subsection{Study Area}

The present study on environmental determinants to household food security was carried out in Kyangwithya West location of Kitui County which lies between latitudes $0^{\circ} 10^{\prime}$ and $3^{\circ} 0^{\prime}$ south and longitudes $37^{\circ} 50^{\prime}$ and $39^{\circ} 0^{\prime}$ east and therefore within the tropical region. It is located in the Kyangwithya West ward in the Central Division of Kitui County which covers an area of $809 \mathrm{~km}$ and borders Kithumula kwa Mutonga, Township, Kwa Vonza/Vonza and Mulango wards. Kitui County can be divided into two climatic zones [25]. Kyangwithya West location is situated in the Western parts of the county and experience high temperatures throughout the year, ranging from $16^{\circ} \mathrm{C}$ to $34^{\circ} \mathrm{C}$ with mean maxima of $28^{\circ} \mathrm{C}$ and mean minima of $22^{\circ} \mathrm{C}$ [7]. The warmest periods are between June and September and January and February. These overall high temperatures in combination with the low and erratic rainfall, result in high rates of evaporation estimated around $1552 \mathrm{~mm} / \mathrm{yr}$ [4] to $1800 \mathrm{~mm} / \mathrm{yr}$ [7].

The rainfall pattern is bimodal. The 'long rains' namely Uua fall in April-May; the 'short rains' namely Nthwa last from October to December, and are more reliable. Annual precipitation ranges from 500 to $1050 \mathrm{~mm} / \mathrm{yr}$, but is highly erratic and unreliable, both spatially and temporally. Overall, approximately $90 \%$ of the annual precipitation falls during the rain seasons [17]. Elevation and topographical features of the landscape strongly influence the amount of rainfall at a regional scale: the higher areas and hill masses in the West receive most rainfall (700-1050 mm/yr), these amounts decline to the South and East where the annual rainfall is less than $500 \mathrm{~mm}$ [7]. It is not uncommon for rains to fail, causing long periods of drought that often result in crop failure and food shortage.

\subsection{Study Population}

According to [21], Kyangwithya West location has a population of 17,223 people with four sub location Tiva, 
Mulutu, Ndumoni and Utooni. In this study, the target population was adults' male or female household heads. The total number of households' (male and female) in the location is 3,198 .

\subsection{Sample Size}

The sample size was derived using Raosoft software with a 95\% confidence level for socio sciences and a margin error of $5 \%$. Sample size was 344 households. Where household heads were absent the person immediately after him/her was interviewed and where none was available, the study moved to the next household to cater for the absent one.

\subsection{Sampling Procedure}

The study utilized systematic sampling to select 344 households. The households were selected proportionate to the population from each sub-location. A sampling frame comprising of a complete listing of all the households (study population) in each sub-location from number 1 to 3,198 was compiled. Thereafter, every $9^{\text {th }}$ household in each sub-location was selected up to the 3,198 household until a sample of 344 was attained. To cater for gender representation, household's heads or person immediately after the household head were interviewed but they were alternated by gender where applicable.

\subsection{Data Collection Methods}

The study utilized mixed methods where both qualitative and quantitative methods of data collection were used. This was intended at providing a comprehensive look at the research problem from many perspectives and thus offers a more complete picture when analyzing results. Questionnaires were used to generate quantitative data while focus group discussions and Key informant interviews generated qualitative data.

\section{Results and Discussions}

\subsection{Weather Change and Household Food Security}

Table 1 revealed that majority of the respondents (89\%) had experienced weather changes in the area while the least number of respondents (11\%) hadn't. The study further established that weather change influenced household food security. Most of the respondents observed weather changes and $27 \%$ of them were food secure while $73 \%$ were food insecure. The results revealed that only few households had not observed any weather change and $28 \%$ were food secure while $78 \%$ were food insecure. Households that observed weather changes were less food insecure compared to households that had noted no change. A discussant narrated that:

"It is not possible to take measures if you have observed no change. For households that observed weather changes they stop selling all their farm produce in anticipation of next harvest season until they are sure that they will harvest by observing the progress of the planted crops"

The findings on experience of weather changes in the area are indications that there are variations in the climatic conditions in the area. These changes, inter alia, have implications for food security. Majority felt that the weather has changed from the way it used to be. Based on their experiences as residents of Kyangwithya West location- many of them have lived in the area for more than 20 year- they were able to ascertain the changes they had witnessed.

These findings show that the difference in food security level for all households despite knowledge of weather change was close. The findings of this study are in conformity with those of [9] in Kitui County which revealed that respondents were aware of changes in weather patterns in their locality which had an implication in food production.

\subsection{Weather Change Experience and Its Influence on Household Food Security}

Table 2 indicated that, inadequate rainfall, high temperatures and recurrent drought were the most observed $(100 \%)$ weather changes in the study area. The results revealed that inadequate rainfall was the most reported weather change by a majority of the respondents (82\%) in the study area. The results further revealed that few respondents (12\%) opined that high temperatures were the main weather change being experienced in the area of study. The results also indicated that a small number of respondents (6\%) observed that recurrent droughts were more often than before. To further establish the influence of the weather change experienced on household food security, descriptive statistics indicated that the highest cause of food insecurity (74\%) resulted due to inadequate rainfall followed by high temperature (72\%) while the weather change noted to contribute the least $(70 \%)$ to food insecurity was recurrent drought.

Table 1. Weather change and household food security

\begin{tabular}{|c|c|c|c|c|c|c|}
\hline \multirow{2}{*}{ Distribution on weather changes } & \multirow{2}{*}{ Frequency } & \multirow{2}{*}{ Percent } & \multicolumn{2}{|c|}{ Food Secure } & \multicolumn{2}{|c|}{ Food insecure } \\
\hline & & & $\mathrm{F}$ & $\%$ & $\mathrm{~F}$ & $\%$ \\
\hline Yes & 305 & 89 & 83 & 27 & 222 & 73 \\
\hline No & 39 & 11 & 11 & 28 & 28 & 78 \\
\hline Total & 344 & 100 & & & & \\
\hline
\end{tabular}

Source: Field survey data (2017). 
Table 2. Weather changes experienced and household food security

\begin{tabular}{|c|c|c|c|c|c|c|}
\hline \multirow{2}{*}{ Distribution of weather change experienced } & \multirow{2}{*}{ Frequency } & \multirow{2}{*}{ Percent } & \multicolumn{2}{|c|}{ Food Secure } & \multicolumn{2}{|c|}{ Food Insecure } \\
\hline & & & $\mathrm{F}$ & $\%$ & $\mathrm{~F}$ & $\%$ \\
\hline High temperatures & 39 & 12 & 11 & 28 & 28 & 72 \\
\hline Recurrent drought & 20 & 6 & 6 & 30 & 14 & 70 \\
\hline Inadequate rainfall & 267 & 82 & 70 & 26 & 197 & 74 \\
\hline Total & 326 & 100 & & & & \\
\hline
\end{tabular}

Source: Field survey data (2017).

Table 3. Influence of cutting trees on household food security

\begin{tabular}{|c|c|c|c|c|c|c|}
\hline \multirow{2}{*}{ Distribution of respondents who cut trees } & \multirow{2}{*}{ Frequency } & \multirow{2}{*}{ Percent } & \multicolumn{2}{|c|}{ Food secure } & \multicolumn{2}{|c|}{ Food Insecure } \\
\hline & & & $\mathrm{F}$ & $\%$ & $\mathrm{~F}$ & $\%$ \\
\hline Yes & 61 & 18 & 12 & 20 & 49 & 80 \\
\hline No & 283 & 82 & 82 & 29 & 201 & 71 \\
\hline Total & 344 & 100 & & & & \\
\hline
\end{tabular}

Source: Field survey data (2017).

This corresponds with the findings of [28] in Wenje Division, Tana River County who reported that majority of households noted that there is a decline in the amount of rainfall received compared to the past. The timing or onset of rains had also changed and this had resulted to a shift in the farming season. This is similar to what was also observed by [8] in their findings that variability in climate disturbs the farming calendar since it results to either an early or delayed onset of rains. Their findings also indicated that the frequency, intensity and duration of dry spells and droughts were alarming. The findings on drought $(70 \%)$ were consistent with a government report which projected that the frequency of droughts and flash floods was expected to increase both in intensity and spread as a result of climate change [14]. More so, drought is a critical indicator for weather changes that has implications for the state of food availability in an area [31]. Increase in temperature was also observed in a similar study in Kaveta and Mikuyuni villages of Kitui County by [9] who noted that there was an increase in temperature over the years.

\subsection{Influence of Cutting Trees on Household Food Security}

The findings of this study as presented in Table 3 indicated that majority of the respondents (82\%) did not cut trees. Only a few households (18\%) did. Further, the study sought to establish the influence of cutting trees on household food security. Using descriptive statistics, the results revealed that majority of the respondents (80\%) that did cut trees in the study area were food insecure. A small portion (20\%) was food secure despite cutting trees. The results further revealed that majority of the respondents in the study area did not cut trees and (29\%) of them were food secure while $71 \%$ were food insecure. The study findings revealed that few households cut trees for food and the few who cut trees are food insecure.
A male discussant indicated that;

"There are no trees to cut down for charcoal and brick burning because the government has stopped all form of logging. You have to obtain a permit from the chief to cut a big tree. The few who cut trees do it in hiding”

The verbatim narrative also indicated that cutting trees was being denied by local administrators in the aim of restoring the lost vegetation cover after years of unrestricted logging. It was also observed that previously trees had been cut down and therefore the tree cover declined and much effort to restore tree cover had been hampered by failing rainfall.

The findings of this study conforms to the findings of [15] which opined that cutting trees for charcoal burning, fuel wood, construction materials and fodder lead to food crises.

\section{Conclusion}

The study revealed that the respondents were aware of changes in weather that had implication of their food security. Further, the study revealed that the main weather changes reported were inadequate rainfall, high temperatures and recurrent drought. The study also revealed that inadequate rainfall was the main cause of food insecurity in the study area. The study revealed that most households did not cut trees for sustenance and the few engaged in cutting trees did it in hiding and were the most food insecure.

\section{Recommendations}

Based on the findings of this study, the study recommends timely communication of weather forecast to households to allow them to make timely plans on planting seasons and seed varieties that would do well under prevailing weather conditions. 


\section{References}

[1] Adak, G. K., Meakins, S. M., Yip, H., Lopman, B. A., and O’Brien, S. J., (2005). Disease risks from foods England and Wales, 1996-2000. Emerging Infect Dis, 11:365-372.

[2] Agricultural Land Advisory Service (ADAS). (2009). RMP/5142 Analysis of Policy Instruments for Reducing Greenhouse Gas Emissions from Agriculture, Forestry and Land Management. Wolverhampton, UK:ADAS UK Ltd.

[3] Avissar, R. and Werth, D. (2005) Global teleconnections resulting from tropical deforestation. Journal of Hydrometeorology. 6: 134-145.

[4] Borst, L., \& de Haas, S.A. (2006). Hydrology of Sand Storage Dams - A case study in the Kiindu catchment, Kitui District, Kenya (Master thesis Hydrogeology Code 45012227 ECTS). /L_Borst_SA_de_Haas_-_Hydrology_of_Sand_Storage_Dams__A_case_study_in_the_Kiindu_catchment_Kitui_District_Kenya_ -_rev1.pdf

[5] Boxall, A. B. A., Hardy, A., Beulke, S., Boucard, T., Burgin, L., and Falloon, P. D. (2009). Impacts of climate change on indirect human exposure to pathogens and chemicals from agriculture. Environ Health Perspect, 117:508-514.

[6] Dalmago, G. A., Bergamaschi, H., Comiran, F., Bianchi, C.A.M., Bergonci, J. I., and Heckler, B. M. M. (2004). Soil temperature in maize crops as function of soil tillage systems. A paper presented at: 13th Conference of International Soil Conservation Organization (ISCO), July, 2004, Brisbane.

[7] District Commissioner Kitui (DCK), (2002). Kitui District Development Plan 2002 - 2008. Kenya, 72 p.

[8] Dhaka, B., Chayal, K., \& Poonia, M. (2010). Analysis of farmers' perception and Adaptation strategies to climate change. Libyan Agriculture Research Centre Journal, 388-390.

[9] Evelyn, J.M., Charles, K. N., \& Patricia, M. (2017) Smallholder Farmers' Perceptions and Adaptations to Climate Change and Variability in Kitui County, Kenya. J Earth Sci Clim Change 8:389.

[10] FAO. (2015). The State of Food Insecurity in the World. Meeting the 2015 international hunger targets: taking stock of uneven progress (available at http://www.fao.org/3/a-i4646e.pdf).

[11] FAO. (1996). 'Rome Declaration on World Food Security and World Food Summit Plan of Action', World Food Summit 13-17 November 1996. Rome.

[12] Field, C.B., Mortsch, L.D., Brklacich, M.. Forbes, D.L., Patz, J. A., Running, S.W. \& Scott M.J. (2007). North America. In: Climate Change 2007: Impacts, Adaptation and Vulnerability

[13] Gichuki, F. N. (2000). Makueni District Profile: Soil Management and Conservation, 1989-1998', Drylands Research Working Paper 4. United Kingdom, Drylands Research ,Crewkerne.

[14] Government of Kenya, (2011). National food and nutrition security policy. Kenya: Government printers

[15] Government of Kenya, (2002). National action programme, a framework for combating desertification in Kenya. National Environment Secretariat, Nairobi, Kenya. pp: 11-14.

[16] Gregory, P., Ingram, J., and Brklacich, M. (2005). Climate change and food security. The Royal Society.

[17] Hoogmoed, M. (2007). Analyses of impacts of a sand storage dam on groundwater flow and storage. VU University, Amsterdam. 165 p.

[18] IPCC. (2007). Climate Change 2007 the physical science basis. Contribution of Working Group I to the Fourth Assessment Report of IPCC. Cambridge. UK. Cambridge University Press.
[19] IWMI [International Water Management Institute] (2010) Managing water for rain-fed agriculture. Water Issue Brief: Issue 10.

[20] Kenya National Bureau of Statistics (KNBS) and Society for International Development (SID). (2013). Exploring Kenya's Inequality: Pulling Apart or Pooling Together. Nairobi: Authors.

[21] Kenya National Bureau of Statistics. (2009). Kenya Population and Housing Census: Population Density by Administrative Units. Nairobi: Author.

[22] Kirtman, B., Power, S.B., Adedoyin, J.A., Boer, G.J., Bojariu, R., Camilloni, I., Doblas-Reyes, F.J., Fiore, A.M., Kimoto, M., Meehl, G.A., Prather, M., Sarr, A., Schär, C., Sutton, R., van Oldenborgh, G.J., Vecchi, G. \& Wang, H.J. 2013. Near-term climate change: projections and predictability. In T.F. Stocker, D. Qin, G.-K. Plattner, M. Tignor, S.K. Allen, J.,Boschung, A. Nauels, Y. Xia, V. Bex \& P.M. Midgley, eds. Climate change 2013: the physical science basis. Contribution of Working Group I to the Fifth Assessment Report of the Intergovernmental Panel on Climate Change, Cambridge, UK, and New York, USA, Cambridge University Press.

[23] Kumagai, T., Kanamori, H., Yasunari, T. (2013) Deforestationinduced reduction in rainfall. Hydrological processes. 27: 3811-3814.

[24] Krishnamurthy, P.K., Hobbs, C. Matthiasen, A., Hollema, S.R., Choularton, R.J., Pahari, K., Kawabata, M. (2013). Climate risk and food security in Nepal: Analysis of climate impacts on food security and livelihoods. CCAFS Working Paper No. 48.

[25] Louis Berger International Inc. (1983). Arid and Semi-Arid Lands Development Project, Kitui District Water Resources Study, Executive Summary, Government of Republic of Kenya.

[26] Mesfin, G. (2004). A study of Land Degradation and Related Policy Measures in Ethiopia, The Case of Amhara Region. April 2004. Wageningen University.

[27] Miano, M. D., Karanja, D., Mutuku, R. Maina, L. (2010). The role of the market in addressing climate change in arid and semi-arid lands of Kenya: the case of Gadam sorghum. Retrieved from: http://www.dewpoint.org.uk/Asset\%20Library/ICID18/14MIANO_et_al_ICID+18.pdf.

[28] Ndegwa. P., Okeyo. B., \& Shauri, H. S. (2015). Assessment of Factors Influencing Food Security in Wenje Division, Tana River County - Kenya. Journal of Food Science and Quality Management www.iiste.org. (Online) Vol.44.

[29] Nyandiko, N.O., Wakhungu, J., Oteng'I, S. B. B. (2012). The predicting crop yields and livestock production in the arid and semi arid lower Eastern Kenya. PhD draft thesis. Masinde Muliro University of Science and Technology, Kakamega, Kenya: 166-182.

[30] Surtech, (1993). Isiolo meat factory project: feasibility study for Isiolo abattoir. Report prepared for the GTZ-Marsabit Development Programme, PO Box 52514, Nairobi.

[31] Shauri, H. S. (2011). Draught and Famine Mitigation Strategies: Basics, Concepts and Strategies, LAP Lambert Academic Publishers, Germany.

[32] UNEP. (1991). Status of Desertification and the Implementation of the United Nations Plan of Action to Combat Desertification. UNEP. Nairobi.

[33] Wheeler, T.R., Crauford, P.Q., Ellis, R.H., Porter, J.R. \& Vara Prasad, P.V. (2000). Temperature variability and the yield of annual crops. Agriculture, Ecosystems and Environment, 82: 159167. 